\title{
Quest for Success: Nicholas Pisacano Scholars Presentation
}

\section{F. Marian Bishop, PhD, MSPH}

I am honored to be with you today because you, as Pisacano Scholars, represent an elite group. There are not many of you, and much is being asked of you.

I was asked to do two things today. The first was to share some recollections about Nicholas Pisacano.

It is unfortunate that you did not know Nick Pisacano. He had many talents, and he was a unique character. You probably already know he had a medical background that came from general practice, before the specialty was reborn as family practice. I am sure you know that he was the first executive director of the American Board of Family Practice.

Did you also know that he read Latin works in their original form, played the piano well enough to pay his medical school expenses, and was a passionate spokesperson for converting general practice into a national and internationally recognized board-certified specialty?

I want to share something about him that some of us knew and many did not. In addition to all his intellectual and cultural accomplishments, Nick was a keen observer of organizational structure and process. As such, he was a great source of inside information about what was happening in the organizations of family medicine.

I used to seek him out and sit by him at the business sessions of the American Academy of Family Physicians. He knew the intrigue behind every controversy, and if he trusted you, you could learn about the inside maneuvering as various proposals were discussed and debated.

From the Department of Family and Preventive Medicine, University of Utah, Salt Lake City. Address reprint requests to F. Marian Bishop, PhD, MSPH, Department of Family and Preventive Medicine, 1C 206 School of Medicine, University of Utah, 30 North 1900 East, Salt Lake City, UT 84132-2118.

This paper was an invited presentation to the Pisacano Scholars.
He always had definite opinions about the merits of the issues under discussion and about the validity of statements various speakers were making. This information would be delivered in a sidebar conversation, and if you did not catch it the first time, it was not repeated. Sitting beside him was an educational experience in interpersonal relationships and organizational intrigue.

In addition to sharing my thoughts about Nick, I was asked to prepare a "presentation about teaching, training, and research in family medicine and how the scholars can assume leadership roles in teaching and research regardless of the setting in which they choose to practice." This stuff is fairly heavy duty for an after-lunch presentation, so I have decided to approach it by telling you a fairy tale.

How many years has it been since your mother told you a fairy tale? Many, I would guess. I am indebted to a colleague in my department, Peter Catinella, MD, MPH, ${ }^{*}$ for this fairy tale, which I heard from him last spring. I was so intrigued by that it has returned to my mind repeatedly since I first heard it. I have chosen to share it with you today.

This tale takes place a long time ago. It has two main characters: the Fisher King and the Perceval, a Knight of the Round Table, and is loosely taken from an analysis prepared by a California psychologist. $^{1}$

\section{Perceval and the Fisher King}

The Fisher King obtained his name because fishing became the only activity to offer him respite from a terrible and unhealing wound. This enduring wound in his groin had castrated him, render-

*Vice Chairman for Primary Care Programs, Department of Family and Preventive Medicine, University of Utah School of Medicine, Salt lake City, Utah. 
ing him sterile and fostering a feeling of inadequacy and helplessness.

Because of his perpetual pain and tormented by his inability to become the successful king he dreamed of being, his kingdom suffered from neglect. It gradually withered into a desolate wasteland. Only the sacred power of a holy chalice entrusted to the Fisher King, the Holy Grail, sustained the king and his kingdom.

Perceval came from a modest background, yet his determination, conviction, and fortitude enabled him to become a Knight of the Round Table. At King Arthur's court, he gained the instruction on knighthood by wise teachers. Although the youthful Perceval demonstrated skill, courage, and strength, he was also impulsive.

Some of his teachers admonished their pupil not to ask questions but to rely on the available information for decision making. He was taught to remain detached, though respectful, and to retain emotional distance throughout his quest. (It reminds me a bit of evidence-based medicine, which is currently so much in vogue.)

Soon Perceval began his quest for the Holy Grail. One day, tired and hungry, with no lodging in sight, he asks a simple fisherman for advice. The fisherman, unknown to Perceval to be the Fisher King himself, invites Perceval to receive his hospitality. He gives Perceval simple but specific directions: go down the road, bear left, and cross the drawbridge.

Perceval complies in gratitude for the offer, but he is skeptical of its veracity, as no estate seemed within his field of vision. Yet he finds and crosses a drawbridge, whereupon a castle magically appears.

That night Perceval watches as a strange but captivating procession unfolds before him. A glistening but fragile sword, a bleeding white lance, and then a radiant dish are all carried to the host, who gives Perceval the sword as a gift. Most amazing of all, however, is a glorious chalice, almost blinding in its luminescence, from which the castle host takes his bread.

Marveling at these sights, Perceval nonetheless remains true to his teaching: a worthy knight asks no questions of his elders. He quietly takes it all in and says nothing.

By morning, when he resumes his quest for the Holy Grail, the castle disappears as he crosses the drawbridge. Stunned, Perceval asks a nearby damsel to help him understand the magic he just wit- nessed. She is amazed that he did not question what he saw. She asks: "How could someone appearing so successful fail to use common sense and distrust his intuition by not questioning what might be occurring?"

For years Perceval wanders. Having shed his knightly armor and surrendered himself to his limitations, Perceval's resemblance to his youth remains only in his steadfast faith and loyalty to his quest.

He now stumbles upon a lake, distraught and weakened by time and fate. A river blocks his route. He asks a fisherman how to best ford the river. The fisherman replies that no nearby crossing is to be found, but to please accept his hospitality and rest. His direction to his home: go down the road, bear left, and cross the drawbridge. This time Perceval, who is by now much wiser, realizes this is the Fisher King and asks the question, "Whom does the Grail serve?" The King replies, "Those who serve the Grail." At that moment the king and kingdom are healed.

\section{The Heroic Myth}

The exhaustive mythology within this tale prevents complete examination, but there are several lessons that this metaphorical tale illustrates: What happens to us when our soul is wounded? Can success occur without constant searching? What is the role of true service? What is the meaning of courage?

First, the wounding of the Fisher King illustrates what happens when our soul is wounded. We live but may not grow nor develop further, especially if we give up searching. We often have to search within our own self and ask the questions.

Second, it is not always the erudite elder who succeeds. Perceval finally succeeds in the quest for success and the Holy Grail. Humble in his beginnings, tenacious in his search, Perceval was true to his calling. Even though he was not successful in his first attempt to find the meaning of the Holy Grail, he continued to search.

The Fisher King's directions help us find our own grail. Within ourselves (down the road), guided sometimes by our intuitive feelings rather than the rational part of ourselves (bear left), we must go to the deeper world of ourselves (cross the drawbridge), wherein lies the secret of success.

There is one more important attribute-that of service. Perceval had to continue to serve in the 
quest for the Grail. For service to occur, he had to keep going and not give up. He had to break with his image of knighthood to find his own image of what being a hero was all about. It is sometimes maintaining momentum and continuing to seek that ultimately results in success.

Once the question is asked, the answer comes from a source greater than one's store of personal wisdom. In this fairy tale, the revelation of the Grail is that meaning to life comes from serving something greater than oneself.

The quest for the Grail is a heroic myth, instructing us in the difficulties we all encounter from time to time, how we suffer, and how to heal the despair and desolation we feel when success does not come easily. It is about reclaiming our humanity and wholeness by extending ourselves beyond what objective reason alone would direct, what convention would command, and what comfort would yield.

Moreover, it is a hopeful tale, one uniquely pertinent to those in medicine, for it also teaches us that whenever we sense ourselves impotent, whenever we feel rejected, whenever we believe success is beyond our grasp, whenever we sense the future has little hope, it might be that we have stumbled upon a wasteland.

Every wasteland holds promise that a nearby castle and a grail lies awaiting our search. We should not ignore our challenges nor hide from our fears of failure. We need not let the fear of past failures color the present or rob the future of its promise.

You have been blessed with the counsel of role models during your years of medical school training and will acquire the wisdom of experience and learning during the next years. As you embark on new careers, we cannot predict what will come to you as a part of your life experience. What we can predict is that you will be molded by time and fate, and that this process is sometimes difficult.

Remember, then, the story of the quest, that hidden within oneself lies salvation. One needs to continue to go down the road, bear left, and cross the drawbridge. Remember also that courage does not always roar. Sometimes courage is the quiet voice at the end of the day saying, "I will try again tomorrow."

You, Scholars, are the future of family medicine. I wish you well and hope you will neither evade nor abdicate nor ignore your duty or your opportunities. The success you bring to your personal quests will dictate the future successes of our discipline.

Go down the road, bear left, and cross the drawbridge.

\section{Reference}

1. Johnson RA. The fisher king and the handless maiden: understanding the wounded feeling function in masculine and feminine psychology. San Francisco, Calif: Harper, 1993. 